use of broadcasting for disseminating information on international problems of the day, whether by documentary talks, round-table broadcasts or international bibliographic information. The use of the same means for disseminating information on the progress of the sciences and on developments in literature and the arts is also discussed, and for planning and sponsoring such programmes the collaboration of leading scientific institutions in different countries should be solicited. The organization of a central international information office is slso proposed, which with regard to scientific information would be in contact with scientific institutions and scientific workers in different countries, and at regular intervals would provide the programme committees with communiqués on recent discoveries and memoranda on new developments. A resolution adopted by the Congress of the Intermational Federation of Associations of Inventors and Industrial Artists recommends that the author of a scientific discovery or invention should not be deprived of his rights because he has himself divulged it in a scientific paper submitted to a learned society or published it in a scientific journal. The resolution also urges an international agreement which in all countries would entitle the author of a scientific discovery or invention to claim a royalty from persons or enterprises utilizing the discovery or invention for industrial purposes.

\section{The School as a Cultural Centre}

A RECENTLY issued bulletin of the United States Office of Education, "The School Building : Situation and Needs" by the official senior specialist in school building problems, emphasizes the view that the State schools, both primary and secondary, must provide, not only for the education of pupils enrolled in ordinary course as at present but also for cultural needs of other members of the community, notably adolescents who have left school but are not at work and adults needing re-education in new lines of work made necessary by industrial changes and for recreation during leisure time. It is clear, says the report, that technological advances and the resulting decrease in the number of workers required in industry are going to "make it necessary for the public schools to provide either full-time or part-time education and recreational opportunities for a large proportion of boys and girls, between eighteen and twenty-one years of age, who are neither in school nor at work. School buildings must be equipped for this purpose. A similar expansion of the purposes of school buildings was advocated in two addresses to Section L (Educational Sciences) of the British Association meeting in August at Cambridge by Mr. W. G. Newton and Mr. S. E. Unwin, county arohitect, Cambridge. The former included in his summary of to-day's requirements to be interpreted in the school architect's building forms "importance of the parent and the use of the school as a cultural centre", while the latter declared that "the school of the future will only be starting its work with child education, it will be a meeting place for people of all ages" ; ". . . for adult activities, even if only for evening classes and adult lectures, a common room where the People can meet for discussion or friendly conversation, with facilities for light refreshment, will be necessary."

\section{Industrial Arts and Education}

THE report of a Committee appointed by the Commissioner of Education to consider the Interpretation of Industrial Arts in American Schools has been published as Bulletin No. 34, 1937, by the United States Department of the Interior (Washington, D.C. : Gov. Printing Office, 15 cents). The report is primarily concerned with the way in which the study of industrial arts can contribute to a programme of education for a society which is fundamentally industrial, and the significance of such study in providing a background for education for citizenship, apart from its value in stimulating the development of creative and artistic abilities, is stressed. The position of industrial arts in the elementary school, the junior high school, the senior high school, in adult education and in higher education is discussed in separate chapters of the report, and particularly in the senior high school, the contribution of industrial arts to vocational training is emphasized as well as its value in safety education. In the broadest sense, safety education in the sense of providing every citizen with an adequate scientific or technical back. ground for the life he or she is called upon to live in this present age is one of our greatest needs, and the report would be worth while if only for the terse but illuminating way in which it indicates opportunities which are at present often missed.

\section{Utilization of British Hardwoods}

Mr. W. A. Robertson, director of the Forest Products Laboratory at Princes Risborough, discussed the utilization of British hardwoods in a paper read before the Department of Forestry of Section K (Botany) at the recent meeting at Cambridge of the British Association. The author dealt with some of the more economic species such as oak, beech, ash, birch, sycamore, alder and poplar. In discussing the more valuable hardwoods, oak, beech, ash, etc., Mr. Robertson pointed to the fact well known to the scientific forester that the poorness of the British present-day timber is due to faulty sylviculture-a position which will not be rectified in Great Britain until recognition by owners of woods is given to the fact that they require just as careful and scientific attention throughout the life of the crop as agriculture. Clean grown timber of any type can only be produced by good sylviculture, in which is included the essential item of correct thinning at specified periods. The coming of plywood has opened new modes of utilization of large-sized hardwoods, since British timber of these species is every whit as good as the foreign. Yet, as Mr. Robertson says, the problem of the disposal of thinnings and cordwood still remains a difficulty.

\section{Long Ashton Research Station}

RECENT developments in fruit products research are described in the Long Ashton Research Station report for 1937. Since 1932 a comprehensive study has been made of the possibilities of utilizing surplus 